\title{
Port-City Development: The Spanish Case
}

\section{Beatriz López-Bermúdez, Maria Jesus Freire-Seoane, Carlos Pais-Montes, Emilio Lesta-Casal}

The objective of this paper is to try to evaluate the port-city relationship from its onset, taking into account the challenges of port 4.0. Indicators such as the percentage of employees participating in training programs, the percentage of female employees in Galician ports, the percentage of merchandise moved by private operators and the percentage of companies with quality certification in Galician ports are evaluated. The fourth revolution is based on the transition from current fossil fuel-based energy models to alternative energy sources, changes in the logistics and transport parameters and finally, on the elimination of intermediation. The key component of the third pillar of new Economy 4.0 is complete digitalization. The optimum port-city solution must address the need of both the urban planner and the port manager to evaluate potential measures that would alleviate the pressure of dedicated port facilities on the city and vice versa to the greatest extent possible.

\section{KEY WORDS}

$\sim$ Port-city

$\sim$ Port 4.0

$\sim$ Automatization

$\sim$ Sustainability a. University of A Coruña, Spain

e-mail: beatriz.lopez2@udc.es

doi: 10.7225/toms.v09.n01.007

This work is licensed under (cc) BY

\section{INTRODUCTION}

Maritime activities have historically been a direct driver of urban growth and the city used to grow hand in hand with its port. Recent advances in transport technology have caused a transition from port-to-port market to door-to-door economy. This observation is described by Norcliffe, et al. (1996), who held the view that until World War II, ports created cities and large ports created large cities. However, the containers, dry ports, railway access and, in short, the development of logistics in the second half of the 20th century have made city size less dependent on port size. The correlation between port dimensions and the size of the city has since grown less direct since the port is now at the service of a much larger region: its hinterland.

In addition, although the economic contribution of the ports has decreased, their social and environmental costs have increased. Problems range from traffic congestion and environmental impact of highly polluting port activities to great competition between the port and the city over land use. (Liao et al., 2010; Salazar and García-Menéndez, 2012). Taken together, these factors gave rise to the "key question" of whether ports and their host cities should be developed together, as integrated economic-functional spaces. Despite the perceived negative externalities in the urban development, ports in large cities have still experienced phenomenal growth. In fact, in recent decades, most of the world's most important ports have been situated in populous cities (Hall and Jacobs, 2012). Research studies often analyze port system structure and the urban-city system separately, with only a few having made an attempt to integrate the two, although this is necessary for a better understanding of the sustainable development of port cities in the face of regulatory and policy changes. 
The optimum port-city solution must address the need of both the urban planner and the port manager to evaluate potential measures that would alleviate the pressure of dedicated port facilities on the city and vice versa to the greatest extent possible. Therefore, urban development projects and private sector investments should strive to open spaces of little or marginal use to the port to the public. The idea is to create an interface between the port and the city, that would allow coexistence between the commercial operations of the port and the recreational vision of the port as the seafront.

The fourth revolution is based on the logical and undoubtedly unstoppable transition from current fossil fuelbased energy models to alternative energy sources, changes in the logistics and transport parameters and the elimination of intermediation. The key component of the third pillar of new Economy 4.0 is complete digitalization. The ports of the future must meet their needs by means of the fourth revolution, always striving for maximum efficiency and effectiveness. The objective is to achieve the balance between the port and the city in terms of sustained development, without compromising the production of future generations, as well as to take advantage of the development of digitalization, embodied in automation and the use of highly sophisticated software in ports.

The objective of this paper is to identify the challenges of port 4.0 from a holistic perspective and evaluate a series of indicators of the Spanish port system, and particularly of the ports of Galicia. The paper is structured as follows: section 1 introduction; section 2 summarizes the port-city relations; section 3 develops the concept of port 4.0; section 4 presents the benchmarking methodology; section 5 presents the results obtained; and finally, the last two sections contain the conclusions and bibliography.

\section{PORT-CITY}

Port-city relations have been characterized by the fact that maritime transportation of goods has undergone a transition from port-to-port to door-to-door concept, resulting in the expansion of the port hinterland into the interior and the consequent urgent need to ensure maximally efficient and effective land transport, entailing the need for an intermodal transport chain that necessarily requires industrial parks or logistic activity zones (hereinafter: "LAZ") where these infrastructures can be located. The port thus acts as a link between the city and its regional development. Apart from facilitating trade and industry, ports also encourage economic progress through the multiplying effect of port cluster activities (Suykens, 1989; Zhang and Lam, 2013). Nevertheless, there is generally (no clear) definition of the concept of port-city "due to the complex interactions of several networks and territories in one place" (Wang and Ducruet, 2012). Port cities are economic entities closely related to maritime activities. In addition, these cities are the link between local and global environments, acting as exchange centers and meeting points of different cultures and environments. Currently, ports are considered to be nodes within the international trade logistics network (Tan, 2007).

The researchers have pointed out that relations between ports and cities greatly vary from region to region. Ducruet (2006) analyzed the interdependence of ports and cities by examining the correlation between the population of the city and port performance. The results have shown European port cities to have a relatively weak but stable interdependence index, while Asian port cities have a stronger, but steadily declining, interdependence. Predominant in Europe, in Asia, controlled markets are concentrated in coastal areas. The conflicts between a port and its city pertain to the congestion of urban traffic and the redevelopment of the seafront (Hayuth, 2007, Wang and Ducruet, 2012). A typical example is the shortage of adequate land and sea space for port expansion (Yap and Lam, 2013). Many port terminals, initially located in the vicinity of the city center in the 1960s and 1980s, now face "increasing competition from high-end real estate, commercial and residential developments due to the gradual expansion of the city center" (Grossmann, 2008; Rondinelli, 2001).

In recent years, with the development of the economies of scale, ports have evolved towards fourth generation ports which, though physically separated, can still be linked by common operators or common administration. Apart from specialization, post-industrial ports are also characterized by the need to optimize their land (truck and rail freight) and maritime access (by dredging to increase drafts and constructing dikes to facilitate shelter). All this highlights the importance of a port's location for the development and maintenance of its terrestrial (hinterland) and maritime (foreland) areas of influence. Another feature, no less important for modern ports, is the new environmental and social sensitivity of the post-industrial city. Thus, the modern port, as the fundamental component of the merchandise distribution system and the point of convergence of various transport systems, can be the subject of environmental and social conflicts that endanger port development itself. All these external factors now have greater importance than in the industrial stage.

The conflicts between the city and the port have affected and resulted in the formation of a negative relationship between the port and the city, ruling out any positive aspects (Xiao and Siu, 2017). However, the port system cannot be separated from the city it serves. Therefore, Hall and Jacobs (2012) attempted to gain a dynamic understanding of the city-port relationship. Their research is one of the few attempts to identify dynamic advantages that urban agglomerations can offer to ports. An in-depth and systematic analysis of the positive and negative aspects of the port-city interaction is required. Studies have to date focused on analyzing the port system separately (Dinwoodie 
et al., 2012, Cetin and Cerit, 2010 and Bekebrede and Mayer, 2006) from the urban one (Baynes, 2009).

\section{PORT 4.0}

The appearance of containers in the 1950s and their proliferation in the 1960s when they became the main axis of maritime transport, resulted in the standardization of cargo handling in TEUs and the development of superstructures (cranes) specialized for their management (Rodrigue, 2017). As for productive processes, following the construction of the first automated containerized goods terminal in Europe in the port of Rotterdam in 1993, semi-automation or automation have been introduced worldwide, but gradually and singularly, since the generalization of this innovative technology / infrastructure has not been achieved.

The new era is characterized by two opposing poles. The negative pole would be container growth rates coming to rival gross domestic product (hereinafter GDP) growth rates, due to the stagnation of China; the positive pole are the new opportunities opened by digitalization, the use of databases, detailed analyses and automation.

The digital age imposes new challenges on an industry traditionally focused on physical assets, altering trade models and creating new value systems. Customer expectations with respect to container traffic are being radically transformed by electronic commerce and innovations in "last-time" logistics, the demands in the container transport industry will only increase, as end consumers expect delivery in the shortest period possible.

As pointed out by McKinsey \& Company (2018), maritime transport is characterized by five aspects to which it must rapidly adapt to be competitive:

- physical characteristics of the industry: container competitiveness depends on loading / unloading, i.e. on crane characteristics and dock operations that connect intermodally;

- world trade flows tend to balance through different routes, as income converges between East Asia and developed economies;

- automation is increasingly present in the logistics supply chain - in ports, terminals, railways and trucks;

- the digital age of data and analysis will fundamentally change the sources of value creation. Customers no longer seek only transport capacities between two locations (containers, terminals and suppliers) and "out of sight, out of mind" orchestration (of freight forwarders);

- industry leaders will greatly change. Some will be the larger versions of the current leaders, emerging from even greater consolidation realized either by focusing on a part or by integration throughout the value chain.
Since the modernization of industrial production processes commenced with the industrial revolution and has been gradually evolving ever since, many authors refer to the current situation as the fourth transport revolution (Schwab, 2017) or the third wave of globalization (McKinsey \& Company, 2018). The so called third wave of globalization in the maritime transport sector is characterized by (McKinsey \& Company, 2018): greater economies of scale, flexibility, reliability and predictability of the supply chain, consolidation and integration, automation and productivity, and environmental performance. However, even though the evolution of maritime transport, as a reference sector of industrial services, has generally been positive, it seems to lag behind when certain relevant factors are analyzed.

A study conducted by McKinsey \& Company (2018) shows that automation has become a trend. The study has shown that $80 \%$ of respondents expect that at least "half of all new port projects will become semi or fully automated" in the next five years, $35 \%$ believe that the share of automated ports will increase by more than $70 \%$. The realization of return on port automation investment was shown to require the effort on the part of port operators, as well as on the part of investors and initial capital outlays are high. It is estimated that the operating expenses of a newly constructed automated terminal would have to be $25 \%$ lower than those of a conventional terminal or productivity $30 \%$ higher and operating expenses $10 \%$ lower to justify these investments. Environmental awareness and the demand for higher quality of life in the cities have become a growing trend. These circumstances will result in the separation of the port from the city. City dwellers see the port as an entity that though attached to the city, is not integrated with, but is rather separate from the city proper, and have a negative attitude to port-generated pollution and the environmental costs of port activities to the city.

The 1st World Conference on Sustainable Transport was held in 2016, where alternatives to road, rail, air, ferry and maritime transport were discussed, as well as, among other issues, climate change, energy, financing and road safety. In his speech, Ban Ki-moon highlighted the importance of action in the transport sector to ensure the implementation of the Paris Agreement on climate change and limit the increase of global temperature. The Conference reflects the dilemma between growth and sustainability. In addition to supporting the achievement of the 2030 Agenda Objectives, it is essential to adopt an approach that would take into account three types of results: economic performance, social dimension and respect for the environment, that will foster interrelation and establish a balance between them. (UNCTAD, 2018). There are many definitions of sustainable transport, each placing emphasis on a different dimension economic (efficient and competitive transport), social (inclusive transport) or environmental (ecological transport). The UNCTAD 
came to the conclusion that the sustainability of maritime transport required balance between the three dimensions. In particular, among other criteria, it requires infrastructures, services and maritime transport operations to be effective, safe, socially acceptable, universally accessible, reliable, affordable, efficient in the use of fuels, environmentally friendly, with low carbon emissions and resilient to climate change.

There is no doubt that increasing the sustainability of the maritime transport sector is essential to realizing the Sustainable Development Goals, as well as the Paris Agreement. Maritime transport is one of the key elements when it comes to environmental protection, since $80 \%$ of traded goods are transported by sea and approximately a quarter of greenhouse gas emissions (UNCTAD, 2018) are estimated to be attributable to this form of transport. However, the application of sustainable maritime transport solutions entails costs and requires additional resources. It is therefore important to increase investment, particularly into new energy sources and mechanisms, and promote greater participation of the private sector, for example, through public-private partnerships that would likewise be subject to sustainability and resilience criteria (European Commission, 2018). The maritime sector is at the crossroads of new developments, in particular, innovations and new digital technologies (UNCTAD, 2018).

At the international level, the International Maritime Organization (IMO, a United Nations agency) has adopted a Strategic Plan for 2018-2023 (Resolution A.1110 (30)). The Strategic Plan identifies the strategic directions on which IMO will focus in 2018-2023, guarantees that the opinions of all stakeholders participating in its decision-making processes will be taken into account and envisages paying special attention to the needs of developing countries, developing island states and the least developed countries (Resolution A.1110 (30)). The strategic directions are as follows:

- Improve implementation.

- Integrate new and advanced technologies into the regulatory framework.

- Respond to climate change.

- Participate in the governance of the ocean.

- Engaging in global facilitation and international trade security.

- $\quad$ Ensure regulatory effectiveness.

- Ensure organizational effectiveness.

Transport activities have a variety of negative external effects, which are often not taken into account in the strategies. These include infrastructural stress, congestion, accidents, pollution (for example, air, noise, the generation of debris) and increasing pressure (Acciaro et al., 2014) of the governments, customers, environmentalists and other interested parties on the transport sector (Sys et al., 2012). This is also true of the port sector, where e.g. external costs are internalized in an attempt to raise ecological awareness, increase the efficiency of resource use and ensure fair competition between transport chains.

\section{BENCHMARKING}

Most practical and theoretical approaches to the assessment of port performances fall into one of the three broad categories (Bichou, 2006): metrics and individual indices, economic impact studies, and efficiency approaches (UNCTAD, 2016).

Benchmarking is a process whereby the strengths and weaknesses of an organization and its advantages over its main competitors are established, best practices identified through the development of a strategic plan aimed at achieving a dominant position over its competitors and subsequently evaluated (Rodrigue et al., 2017; Tovar and Rodríguez-Déniz, 2015; Hokey and Jong, 2006; Cuadrado et al., 2004). Information on port management and operations are required for analysis of port performance (Doer and Sánchez, 2006).

Port performance indicators are relatively simple to obtain and understand from financial information or operational conditions. Given the difficulty of gaining access to financial information in ports, we chose indicators that can be derived from the sustainability memories of the Spanish port system. In their Sustainability Reports, Puertos del Estado and port authorities make manifest their commitment to transparent management by providing an overview of achievements made and challenges faced in fields such as competitiveness, quality of service provision, efficient use of resources, environmental, economic and social impact (Puertos del Estado, 2019).

The port-city research field is new and hugely important (Schipper at al., 2017; Ducruet et al., 2018; Monios et al., 2018; Van der Berghe and Daamen, 2020). At present, there have been no further developments in indicator evaluation, but the quality of companies that operate in the port, the reduction of the gender gap in the labor market, continuous training and public-private partnerships will certainly contribute to the better integration of port-city aspects. Consequently, indicators analyzed in this research are the percentage of companies with quality certification, the percentage of female port employees, the percentage of employees participating in training programs and the percentage of merchandise moved by private operators. Evaluation is based on the comparison of these same indicators with those of companies operating in the cities adjacent to the ports, as well as on the presence / importance of private operators, i.e. private companies in the port and the situation of port employees residing in the cities. All these elements taken together give us an image of the port-city, although further investigation is desirable where more data are available.

Available information suggest that the percentage of companies operating in the port that have quality certificates or recognize quality standards is indicative of port-city 
integration, since quality standards include social, economic and environmental standards. In addition, data on the percentage of merchandise moved by private operators is analyzed, since the majority of Spanish terminals use the landlord system, i.e. land is granted to private operators for exploitation, which indirectly affects both the creation of private companies and jobs. Secondly, the percentage of female employees and employees participating in training programs are two characteristics of the labor market and ports were initially recognized as drivers of the labor markets in their host cities.

\section{RESULTS}

The analysis was conducted by means of evaluation of the selected indicators for the Spanish port system for 2013-2016. A total of 46 ports of general interest have been taken into account.
In particular, the situation in Galician ports (A Coruña, Ferrol-San Cibrao, Marín, Vigo and Vilagarcía) was evaluated, also taking into account the Spanish port with the highest values and the Spanish average obtained from 28 port authorities.

Figure 1 shows the percentage of companies that have quality certificates or recognize quality standards in the total number of companies operating in the port. The greatest percentage of companies with these characteristics in Spain was recorded in the Mediterranean port of Valencia. The indicator analyzed oscillates between $8.61 \%$ in 2013 and $6.92 \%$ in 2016 . The Galician port of Ferrol continuously has values above the national average, between $2.27 \%$ in 2013 and $2.67 \%$ in 2016 . As of 2015, Vilagarcía has likewise been exceeding the average value, reaching $4.35 \%$ in 2016 . However, the port of Vigo is below $1 \%$ and there are no available data on the port of A Coruña.

Figure 1.

Percentage of companies with quality certification in Galician ports and the national average,

Source: own elaboration.

Companies with quality certification are evaluated by external agencies and take sustainable management into account in all their areas of activity. Increased presence of this type of company in the city is beneficial for both economic growth and sustainable development of the port and its entire hinterland.

Figure 2 illustrates the percentage of merchandise moved by private operators in the ports. The port with the highest percentage of merchandise moved by private operators is the port of Valencia, where it accounts for nearly $100 \%$ of merchandise moved. In the period analyzed, all Galician ports except Ferrol have been below the state average of approximately $60 \%$ in the last two years. The port with the lowest percentage (under $50 \%$ ) of private operators is Vilagarcía, while A Coruña and Vigo approach $60 \%$. It is important to note that Ferrol experienced significant growth, reaching $91 \%$ in 2016.

The presence of private operators at the terminals boosts both maritime trade and the labor market. Although the values recorded are below the state average, they are very close to $50 \%$ and the trend seems to be stabilization or even growth as in the case of Ferrol. 


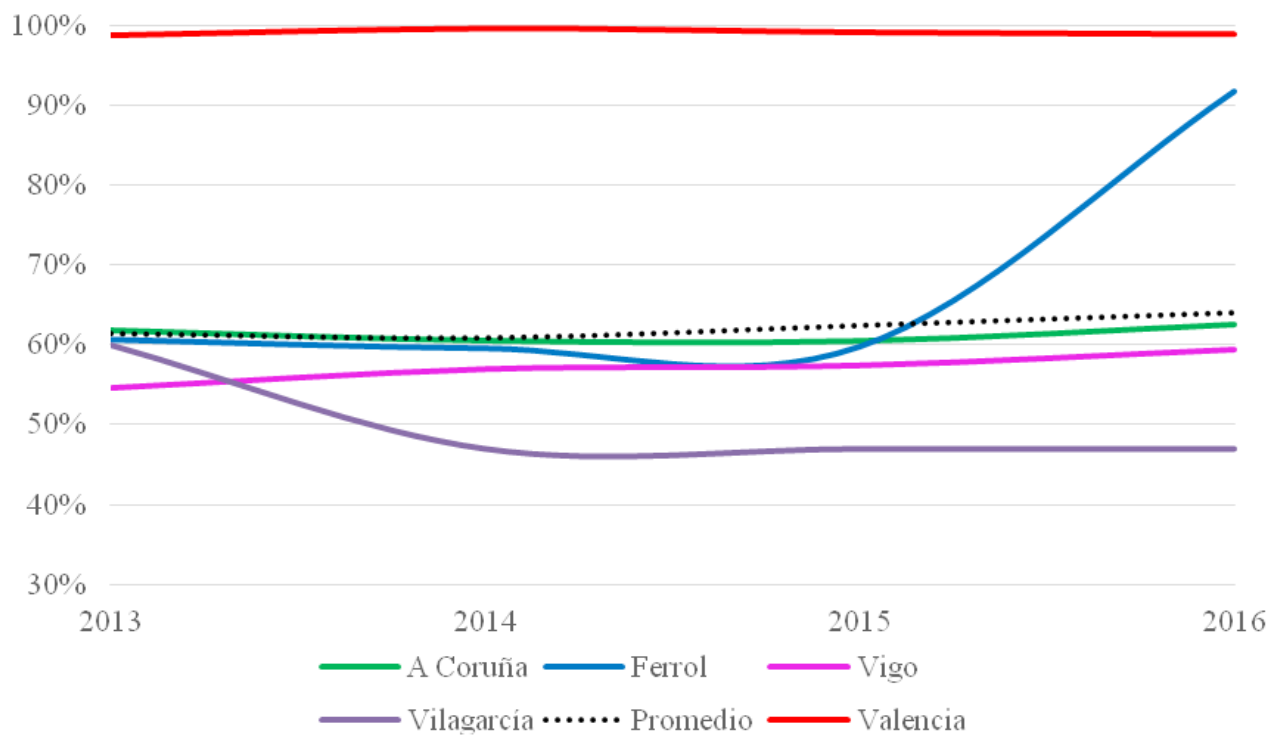

Figure 2.

Percentage of merchandise moved by private operators in Galician ports and the national average.

Source: own elaboration

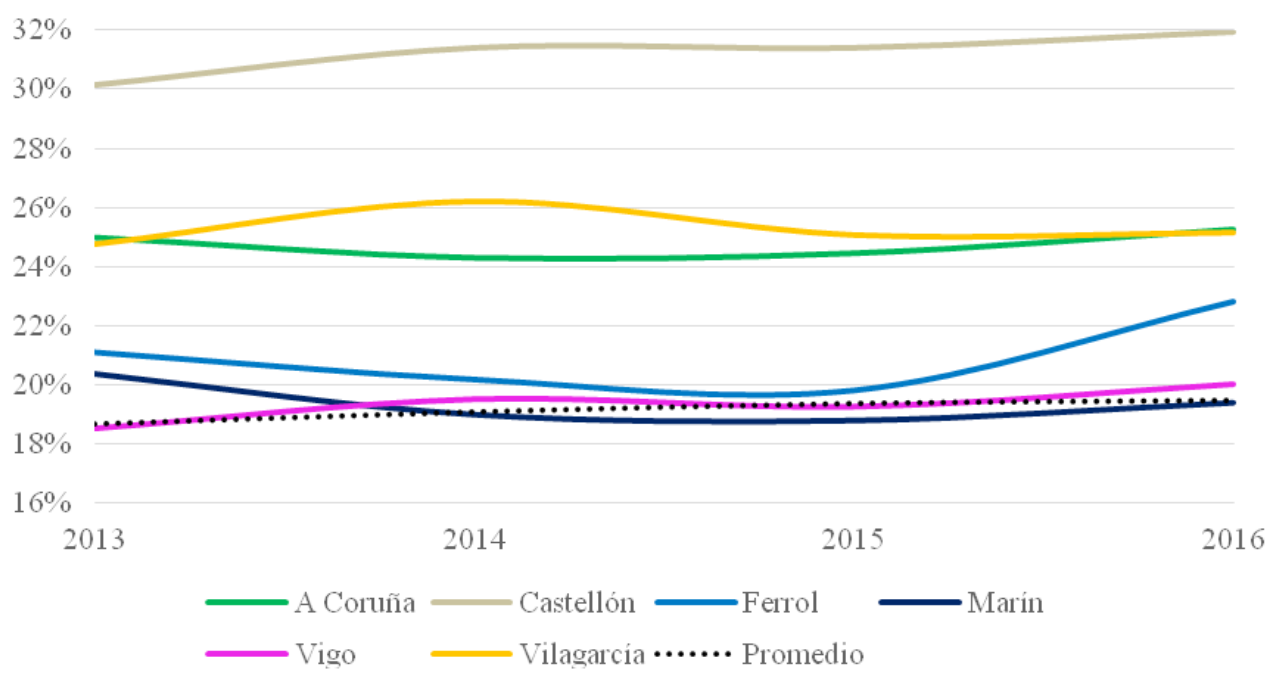

Figure 3.

Percentage of female employees in Galician ports and the national average.

Source: own elaboration

Figures 3 and 4 show data relevant for the labor market: first, the percentage of women working in ports, and then the percentage of employees participating in training programs. Labor market evaluation was reduced to these two indicators due to the limited availability of data. The evolution of the number of women in this traditionally male sector is very significant given the changes in the market and the necessary start-up of industry 4.0 .

The port with the highest percentage of female employees in the entire Spanish port system is the Mediterranean port of 


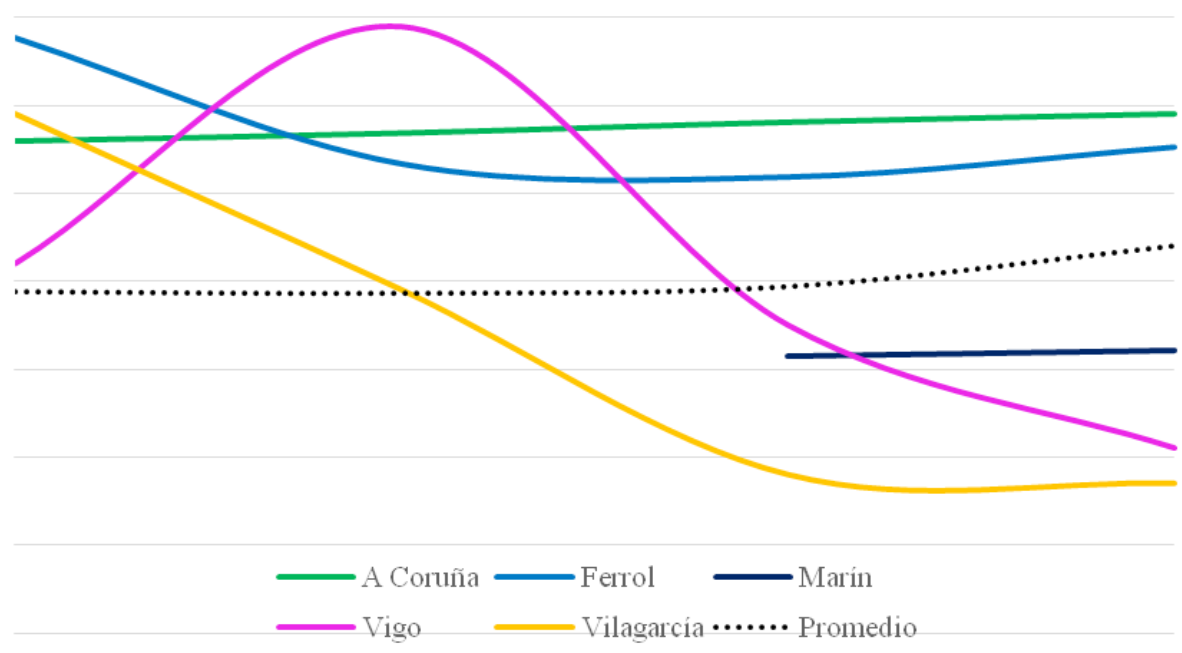

Figure 4.

Percentage of employees participating in training programs in Galician ports.

Source: own elaboration

Castellón, with values above $30 \%$. In absolute terms, the port of Castellón had 38 female employees in the period analyzed, which coincides with the average number of women in 28 port authorities. The percentage of female employees is lower in Galician ports, though still above the national average, with the exception of the port of Marín. The port of Vilagarcía has the highest percentage of female employees, followed by A Coruña, both having values above $24 \%$. Ferrol was around $20 \%$ before exceeding $22 \%$ in 2016. Vigo comes close to the state average of just under $20 \%$. In absolute terms, A Coruña has 43, Ferrol 25, Vigo 46 and Vilagarcía 18 female employees.

Figure 4 illustrates the percentage of employees participating in training programs. Available information has shown the state average to be approx. $70 \%$ of employees participating in training programs. These values are higher than the state average in the ports of A Coruña and Ferrol, in which they included almost $90 \%$ of the workforce in 2016 . However, the trend in Vilagarcía and Vigo was that of decrease, falling below the national average in 2015, and dropping to only $50 \%$ of the workforce in 2016. Data for the port of Marín were not available until 2015, and the values have since been around $60 \%$.

\section{CONCLUSIONS}

Port-city integration can be considered an intrinsic characteristic of all coastal localities that have achieved economic hegemony or rather realized growth through maritime trade, as a factor that eliminates geographical barriers. The port- city relationship has its advantages and disadvantages, but the development of port 4.0 with a 'blue' perspective is expected to contribute to a sustained and sustainable growth of global economy.

In the first place, the evolution of the term port-city needs to be controlled, i.e. we need to control unifying elements such as companies operating in ports, the labor market and environmental protection measures. If the advantages of this relationship are to be separated from its disadvantages, the evaluation of more complex indicators is required.

Second, in order to take advantage of new technologies, lower their costs and expand their competitive advantage, both the city and the port must prepare for the 4.0 revolution.

Third, since automation must be linked to other aspects, e.g. generate benefits for the city, a number of indicators of the quality of companies operating in the ports have been analyzed.

Fourth, companies with quality certification are evaluated by external agencies and take sustainable management into account in all their areas of activity. Increased presence of this type of company in the city is beneficial for both economic growth and sustainable development of the port and its entire hinterland.

Finally, the analysis of certain indicators of the port labor market, such as the percentage of female employees, has shown that this industry continues to be dominated by men. Employee training, including generic training and training in process updates, and especially in new technologies is considered to be important. 


\section{REFERENCES}

Acciaro, M. et al., 2014. Environmental sustainability in seaports: a framework for successful innovation. Maritime Policy \& Management, 41(5), pp. 480-500. Available at:

http://dx.doi.org/10.1080/03088839.2014.932926.

Baynes, T.M., 2009. Complexity in Urban Development and Management. Journal of Industrial Ecology, 13(2), pp. 214-227. Available at: http://dx.doi.org/10.1111/j.1530-9290.2009.00123.x.

Bekebrede, G. \& Mayer, I., 2006. Build your seaport in a game and learn about complex systems. J. of Design Research, 5(2), p. 273. Available at: http://dx.doi.org/10.1504/jdr.2006.011366.

Bichou, K., 2006. Chapter 24 Review of Port Performance Approaches and a Supply Chain Framework to Port Performance Benchmarking. Research in Transportation Economics, 17, pp. 567-598. Available at: http://dx.doi.org/10.1016/s0739-8859(06)17024-9.

Cuadrado, M., Frasquet, M. \& Cervera, A., 2004. Benchmarking the port services: a customer oriented proposal. Benchmarking: An International Journal, 11(3), pp.320-330. Available at:

http://dx.doi.org/10.1108/14635770410538781

Dinwoodie, J. et al., 2011. Sustainable Development of Maritime Operations in Ports. Business Strategy and the Environment, 21(2), pp.111-126. Available at: http://dx.doi.org/10.1002/bse.718.

Ducruet, C. \& Lee, S.-W., 2006. Frontline soldiers of globalisation: Port-city evolution and regional competition. GeoJournal, 67(2), pp.107-122. Available at: http://dx.doi.org/10.1007/s10708-006-9037-9.

Ducruet, C., Cuyala, S. \& El Hosni, A., 2018. Maritime networks as systems of cities: The long-term interdependencies between global shipping flows and urban development (1890-2010). Journal of Transport Geography, 66, pp.340-355. Available at:

http://dx.doi.org/10.1016/j.jtrangeo.2017.10.019.

European Comission, 2018. Investing in Sustainable Development. The EU at the forefront in implementing the Addis Ababa Action Agenda. Available at: https://bit. ly/2FmimpT.

Grossmann, I., 2008. Perspectives for Hamburg as a port city in the context of a changing global environment. Geoforum, 39(6), pp.2062-2072. Available at: http://dx.doi.org/10.1016/j.geoforum.2008.04.011.

Hall, P.V. \& Jacobs, W., 2012. Why are maritime ports (still) urban, and why should policy-makers care? Maritime Policy \& Management, 39(2), pp.189-206. Available at: http://dx.doi.org/10.1080/03088839.2011.650721.

Hayuth, Y., 2007. Globalisation and the port-urban interface: conflicts and opportunities. International Workshop on Ports, Cities and Global Supply Chains, Hong Kong, China.

Liao, C.-H. et al., 2010. The impact of an emerging port on the carbon dioxide emissions of inland container transport: An empirical study of Taipei port. Energy Policy, 38(9), pp.5251-5257. Available at: http://dx.doi.org/10.1016/j.enpol.2010.05.018.

McKinsey \& Company, 2018. Brave new world? Container transport in 2043. Available at: https://mck.co/36mvZkV.

Min, H. \& Joo, S., 2009. Benchmarking third-party logistics providers using data envelopment analysis: an update $\mathrm{H}$. Min, ed. Benchmarking: An International Journal, 16(5), pp.572-587. Available at: http://dx.doi.org/10.1108/14635770910987814.

Monios, J., Bergqvist, R. \& Woxenius, J., 2018. Port-centric cities: The role of freight distribution in defining the port-city relationship. Journal of Transport Geography,
66, pp.53-64. Available at:

http://dx.doi.org/10.1016/j.jtrangeo.2017.11.012.

Norcliffe, G., Bassett, K. \& Hoare, T., 1996. The emergence of postmodernism on the urban waterfront. Journal of Transport Geography, 4(2), pp.123-134. Available at: http://dx.doi.org/10.1016/0966-6923(96)00005-1.

Puertos del Estado, 2019. Web Puertos del Estado: Sustainability Reports. Available at: http://www.puertos.es/es-es/Paginas/Memorias-de-Sostenibilidad.aspx.

Rodrigue, J.P., 2017. The geography of transport system. Routledge, New York.

Rondinelli, D.A., 2001. Making Metropolitan Areas Competitive and Sustainable in the New Economy. Journal of Urban Technology, 8(1), pp.1-21. Available at: http://dx.doi.org/10.1080/10630730120052154.

Saz-Salazar, S. del, García-Menéndez, L. \& Feo-Valero, M., 2012. Meeting the environmental challenge of port growth: A critical appraisal of the contingent valuation method and an application to Valencia Port, Spain. Ocean \& Coastal Management, 59, pp.31-39. Available at: http://dx.doi.org/10.1016/j.ocecoaman.2011.12.017.

Schipper, C.A., Vreugdenhil, H. \& de Jong, M.P.C., 2017. A sustainability assessment of ports and port-city plans: Comparing ambitions with achievements. Transportation Research Part D: Transport and Environment, 57, pp.84-111. Available at: http://dx.doi.org/10.1016/j.trd.2017.08.017.

Schwab, K., 2017. The fourth industrial revolution. Currency.

Suykens, F., 1989. The city and its port-an economic appraisal. Geoforum, 20(4), pp.437-445. Available at: http://dx.doi.org/10.1016/0016-7185(89)90027-4.

Sys, C., Vanelslander, T., Adriaenssens, M., \& Van Rillaer, I., 2016. International emission regulation in sea transport: Economic feasibility and impact. Transportation Research Part D: Transport and Environment, 45, pp. 139-151.

Tan, T.-Y., 2007. Port cities and hinterlands: A comparative study of Singapore and Calcutta. Political Geography, 26(7), pp.851-865. Available at: http://dx.doi.org/10.1016/j.polgeo.2007.06.008.

Tovar, B. \& Rodríguez-Déniz, H., 2015. Classifying Ports for Efficiency Benchmarking: A Review and a Frontier-based Clustering Approach. Transport Reviews, 35(3), pp.378-400. Available at:

http://dx.doi.org/10.1080/01441647.2015.1016473.

UNCTAD, 2016. Port Management Series. Volumen 4. Port Performance. Linking Performance Indicators to Strategis Objectives. Available at: https://bit.ly/2SNotM3.

UNCTAD, 2018. Review of Maritime Transport 2018. Available at: https://bit. ly/2Qjnlhn.

Van den Berghe, K. \& Daamen, T., 2019. From Planning the Port/City to Planning the Port-City. Exploring the Economic Interface in European Port Cities. Available at: http://dx.doi.org/10.31235/osf.io/qtuyf.

Wang, C. \& Ducruet, C., 2012. New port development and global city making: emergence of the Shanghai-Yangshan multilayered gateway hub. Journal of Transport Geography, 25, pp.58-69. Available at: http://dx.doi.org/10.1016/j.jtrangeo.2012.07.008.

Yap, W.Y. \& Lam, J.S.L., 2013. 80 million-twenty-foot-equivalent-unit container port? Sustainability issues in port and coastal development. Ocean \& Coastal Management, 71, pp.13-25. Available at: http://dx.doi.org/10.1016/j.ocecoaman.2012.10.011.

Zhang, W. \& Lam, J.S.L., 2013. Maritime cluster evolution based on symbiosis theory and Lotka-Volterra model. Maritime Policy \& Management, 40(2), pp.161-176. Available at:

http://dx.doi.org/10.1080/03088839.2012.757375. 